simultaneously to give blood from donors and remove blood from the patient. Polyvinyl tubing and Teflon catheters are used to lessen the risk of blood-clotting. In four patients suffering from hepatic coma this method of treatment was given. Blood values showed improvement and one patient recovered. It is postulated that unmodified blood transfusion has a place in treatment of liver failure particularly when associated with severe bleeding.

We wish to thank Dr. Morris C. Davis and Dr. J. L. Frew for permission to report Cases 1 and 3 respectively, and to Dr. J. A. Forbes for permission to report Cases 2 and 4 .
REFERENCES Bcrger, R. L., Liversage, R. M., Chalmers, T. C., Graham, J. H.,
MicGoldrick, D. M., and Stohlman, F. (1966). New Engl. F. Med., 274, 497.

Griffith, G. C., and Boggs, R. P. (1966). Controversy in Internal Medicine, edited by F.J. Ingelfinger, A. S. Relman, and M. Finland, p. 115. London.

Lee, C., and Tink, A. (1958). Med. F. Aust., 1, 40.

Seldinger, S. I. (1953). Acta radiol. (Stockh.), 39, 368

Smith, J. (1941). Aust. N.Z. F. Surg., 10, 384.

Trey, C., Burns, D. G., and Saunders, S. J. (1965). S. Afr. med. 7., 39. 858.

\title{
Survey of Influenza Antibody in England by the Strain-specific Complement-fixation Test
}

\author{
MARGUERITE S. PEREIRA,* M.D. ; PRATIMA CHAKRAVERTY,* B.SC. \\ T. M. POLLOCK, $\dagger$ M.B., M.R.C.P.GLASG. ; J. G. POPE, $\dagger$ B.SC.
}

Brit. med.7., 1967, 4, 80-82

The susceptibility of a community to current strains of influenza virus is an important factor in the development of epidemics of influenza. Predictions of the likelihood of such epidemics and therefore recommendations for the use of vaccines against influenza should be based on what is known of the susceptibility of the population at risk and on the identity of circulating virus strains.

The influenza antibody survey described here was made to estimate the susceptibility to influenza viruses of all age groups in populations in several areas of England.

The laboratory tests previously used to determine antibody to influenza have certain drawbacks. Thus the haemagglutination inhibition test is sometimes difficult to interpret, since virus strains vary in their avidity for antibody and in their sensitivity to nonspecific inhibitors present in serum. Also the serum neutralization test in tissue culture is laborious and expensive.

By contrast the complement-fixation test is simple, and, as a microtest, economical in reagents. This test may be done by using as antigen either the type-specific $S$ antigen or the subtype or strain-specific $\mathrm{V}$ antigen (Lief and Henle, 1956). The former is excellent for the diagnosis of acute influenzal illness, but because the antibody titre declines soon after infection it cannot be used to detect residual antibody. In addition to this limitation the soluble antigen is common to all influenza $A$ viruses and will not react solely with influenza $A_{2}$ antibody.

By the development of the $\mathrm{V}$ antigen, strain-specific reactions were obtained in the complement-fixation test. Henle et al. (1958) demonstrated the value of this test for the antigenic analysis of influenza virus and showed also that antibody detected with the $\mathrm{V}$ antigen would persist for several years after infection. It seemed likely that this would indicate the proportion of a population which had already experienced influenza $\mathrm{A}_{2}$ virus infection. The strain-specific complementfixation test was therefore employed in this investigation.

\section{Materials and Methods}

Public health laboratories in five different locations in England sent samples of serum each week to the Virus Reference Laboratory during the period October 1965 to May 1966. These samples were selected by the sending laboratory from the number submitted for various routine tests, the majority being for the estimation of antistreptolysin $O$ titres or for Wassermann reactions. Sera from patients with acute respiratory illness were excluded. From October 1965 to January 1966 a first series of 729 sera were examined, and from January to May 1966 a second series of 1,054 sera.

Virus Strains.-In the first series sera were tested against a single $V$ antigen prepared with influenza $A_{2} /$ England/7/65 virus. For the second series three $\mathrm{V}$ antigens were prepared with the influenza $A_{2} /$ Singapore/1/57, $A_{22} /$ England/129/66, and $\mathrm{B} /$ England $/ 5 / 66$ viruses.

Antigens.-These were prepared by the methods of Lief and Henle (1956). Allantoic fluids were harvested from eggs inoculated 48 hours previously with the strains of influenza virus. The virus harvests were adsorbed to fowl cells at $0^{\circ} \mathrm{C}$., followed by elution into small volumes of phosphate-buffered saline at $\mathrm{pH} 7.2$ over a period of three to four hours. This cycle was repeated two or three times. The final eluates were then tested quantitatively for specific complement fixation by the chessboard method against a homologous antiserum prepared in ferrets and against an $S$ specific antiserum prepared in guinea-pigs. The dilution of each antigen for use was taken to be that which fixed complement with the highest dilution of homologous ferret antiserum. This varied between $1 / 4$ and $1 / 32$. If there was fixation of complement with the $S$ specific antiserum, further adsorption-elution cycles were done.

Complement-fixation Test.-The method was described by Pereira et al. (1964). It used $0.025 \mathrm{ml}$. unit volumes of the reagents in W.H.O. plastic plates and overnight fixation at $+4^{\circ} \mathrm{C}$. Sera were diluted in fourfold steps and mixed with the optimal dilution of the appropriate $\mathrm{V}$ antigen. Titres were recorded as the reciprocal of the highest serum dilution producing $50 \%$ fixation with the antigen.

\section{Results}

There was no indication of any appreciable difference in the results of tests on the sera from the different laboratories. In the analysis all the results have therefore been combined.

\footnotetext{
* Virus Reference Laboratory, Central Public Health Laboratory, London

+ Epidemiological Research Laboratory, Central Public Health Laboratory, London N.W.9.
} 


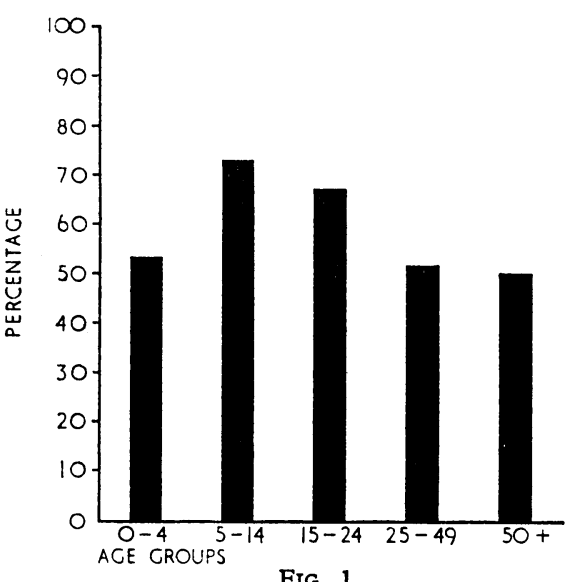

Fig. 1

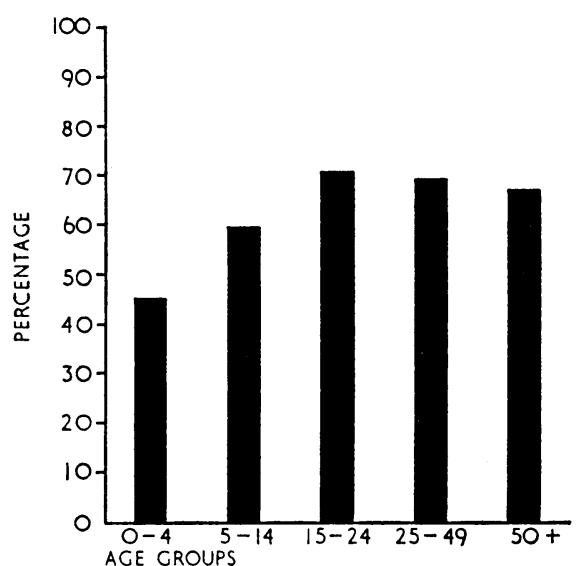

Fig. 2

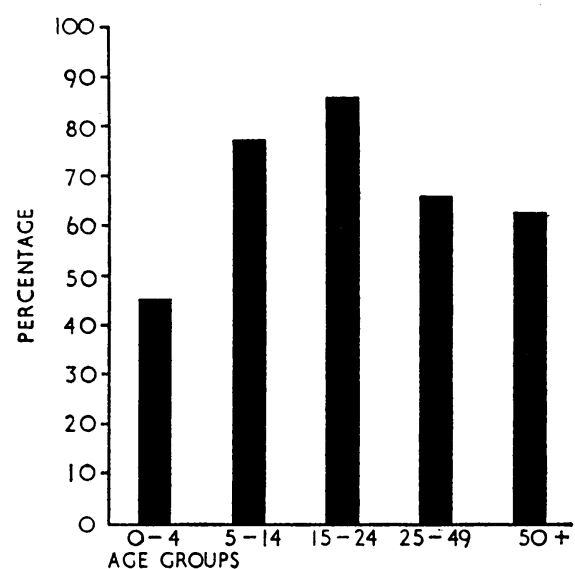

FIG. 3

FIG. 1.-Percentage of individuals with antibody to $\mathrm{A}_{2} / 65 \mathrm{~V}$ antigen by age groups-all areas. October 1965 to January 1966 . Fig. 2.-Percentage of individuals with antibody to $\mathrm{A}_{2} /$ England/66 by age groups - all areas. January to May 1966. Frg. 3.-Percentage of individuals with antibody to $A_{2} /$ Singapore/57 by age groups-all areas. January to May 1966.

As shown in Tables I-III and in Figs. 1-3, a substantial proportion of sera from each age group contained antibody to each of the influenza $A$ antigens. Antibody to the earliest strain, $A_{2} /$ Singapore $/ 1 / 57$, was found most of ten. In persons aged 5-24 years few were without demonstrable antibody, and their sera included the greatest number with high titres against all the strains tested.

The antibody titres to each of the two A antigens in sera from 49 children under 5 years of age are shown in Fig. 4. Despite the antigenic shift of the influenza A strains since 1957 considerable crossing was found and antibody could be demonstrated in most instances against both variants. In the majority the titres were higher against the more recent strain.

TABLE I.-Specific Antibody to Influenza $A_{2} /$ England/7/65 V Antigen.

\begin{tabular}{|c|c|c|c|c|c|c|c|c|c|c|}
\hline \multirow{2}{*}{$\underset{\text { Group }}{\text { Age }}$} & \multicolumn{9}{|c|}{ Antibody Titre } & \multirow{2}{*}{ Total } \\
\hline & $<4$ & 4 & 8 & 16 & 32 & 64 & 128 & 256 & 512 & \\
\hline $\begin{array}{c}0-4 \\
5-14 \\
15-24 \\
25-49 \\
50+\end{array}$ & $\begin{array}{r}19(46 \%) \\
52(27 \%) \\
47(32 \%) \\
103(48 \%) \\
68(50 \%)\end{array}$ & $\begin{array}{r}3 \\
14 \\
7 \\
15 \\
6\end{array}$ & $\begin{array}{r}5 \\
13 \\
13 \\
12 \\
10\end{array}$ & $\begin{array}{r}2 \\
27 \\
16 \\
19 \\
17\end{array}$ & $\begin{array}{r}2 \\
30 \\
21 \\
19 \\
13\end{array}$ & $\begin{array}{l}1 \\
29 \\
24 \\
17 \\
11\end{array}$ & $\begin{array}{r}2 \\
14 \\
8 \\
17 \\
6\end{array}$ & $\begin{array}{r}7 \\
9 \\
9 \\
11 \\
6\end{array}$ & $\begin{array}{l}-1 \\
1 \\
3 \\
\end{array}$ & $\begin{array}{r}41 \\
189 \\
146 \\
216 \\
137\end{array}$ \\
\hline
\end{tabular}

\begin{tabular}{|c|c|c|c|c|c|c|c|c|c|}
\hline \multirow{2}{*}{$\begin{array}{c}\text { Age } \\
\text { Group }\end{array}$} & \multicolumn{8}{|c|}{ Antibody Titre } & \multirow{2}{*}{ Tota } \\
\hline & $<8$ & 8 & 16 & 32 & 64 & 128 & 256 & 512 & \\
\hline $\begin{array}{c}0-4 \\
5-14 \\
15-24 \\
25-49 \\
50+\end{array}$ & $\begin{array}{r}27(55 \%) \\
104(41 \%) \\
64(29 \%) \\
76(30 \%) \\
93(33 \%)\end{array}$ & $\begin{array}{r}3 \\
22 \\
19 \\
26 \\
32\end{array}$ & $\begin{array}{r}2 \\
16 \\
21 \\
22 \\
37\end{array}$ & $\begin{array}{r}7 \\
39 \\
35 \\
31 \\
32\end{array}$ & $\begin{array}{r}3 \\
24 \\
34 \\
49 \\
36\end{array}$ & $\begin{array}{l}2 \\
11 \\
15 \\
21 \\
25\end{array}$ & $\begin{array}{r}3 \\
23 \\
9 \\
14 \\
14\end{array}$ & $\begin{array}{r}2 \\
13 \\
23 \\
15 \\
10\end{array}$ & $\begin{array}{r}49 \\
252 \\
220 \\
254 \\
279\end{array}$ \\
\hline
\end{tabular}

TABLE III.-Specific Antibody to Influenza $A_{2} /$ Singapore/1/57 V Antigen. All Laboratories-fanuary to May 1966

\begin{tabular}{|c|c|c|c|c|c|c|c|c|c|}
\hline \multirow{2}{*}{$\underset{\text { Group }}{\text { Age }}$} & \multicolumn{8}{|c|}{ Antibody Titre } & \multirow{2}{*}{ Tota } \\
\hline & $<8$ & 8 & 16 & 32 & 64 & 128 & 256 & 512 & \\
\hline $\begin{array}{c}0-4 \\
5-14 \\
15-24 \\
25-49 \\
50+\end{array}$ & $\begin{array}{r}27(55 \%) \\
57(23 \%) \\
30(14 \%) \\
88(34 \%) \\
106(38 \%)\end{array}$ & $\begin{array}{r}4 \\
20 \\
17 \\
32 \\
26\end{array}$ & $\begin{array}{r}4 \\
26 \\
37 \\
26 \\
35\end{array}$ & $\begin{array}{l}7 \\
36 \\
35 \\
36 \\
41\end{array}$ & $\begin{array}{r}2 \\
54 \\
46 \\
35 \\
41\end{array}$ & $\begin{array}{r}3 \\
18 \\
15 \\
10 \\
12\end{array}$ & $\begin{array}{r}1 \\
29 \\
21 \\
18 \\
14\end{array}$ & $\begin{array}{r}1 \\
12 \\
19 \\
9 \\
4\end{array}$ & $\begin{array}{r}49 \\
252 \\
220 \\
251 \\
273\end{array}$ \\
\hline
\end{tabular}

TABLE IV.-Specific Antibody to Influenza B/England/5/66 V Antigen, All Laboratories-fanuary to May 1966

\begin{tabular}{|c|c|c|c|c|c|c|c|c|c|}
\hline \multirow{2}{*}{$\begin{array}{l}\text { Age } \\
\text { Group }\end{array}$} & \multicolumn{8}{|c|}{ Antibody Titre } & \multirow{2}{*}{ Total } \\
\hline & $<4$ & 8 & 16 & 32 & 64 & 128 & 256 & 512 & \\
\hline $\begin{array}{c}0-4 \\
5-14 \\
15-24 \\
25-49 \\
50+\end{array}$ & $\begin{array}{r}37(75 \%) \\
144(57 \%) \\
81(37 \%) \\
123(48 \%) \\
155(55 \%)\end{array}$ & $\begin{array}{r}3 \\
20 \\
24 \\
37 \\
36\end{array}$ & $\begin{array}{r}2 \\
12 \\
14 \\
11 \\
11\end{array}$ & $\begin{array}{r}2 \\
25 \\
35 \\
39 \\
35\end{array}$ & $\begin{array}{r}2 \\
15 \\
21 \\
19 \\
14\end{array}$ & $\begin{array}{l}1 \\
13 \\
20 \\
15 \\
18\end{array}$ & $\begin{array}{r}1 \\
8 \\
10 \\
6 \\
5\end{array}$ & $\begin{array}{r}1 \\
15 \\
14 \\
4 \\
5\end{array}$ & $\begin{array}{r}49 \\
252 \\
219 \\
254 \\
279\end{array}$ \\
\hline
\end{tabular}

In Table IV and Fig. 5 the presence of antibody against influenza $B$ is shown to be relatively infrequent in sera from preschool children, but this incidence has increased sharply in the older children, reaching a peak among the young adults. The outbreaks of influenza B infection which occurred in many schools throughout the country in the early months of 1966 may have had a considerable influence on the formation of this pattern.

\section{Discussion}

Though the presence or absence of immunity to the current virus strains is a principal influence in the development of epidemics, there have been few attempts in England to assess

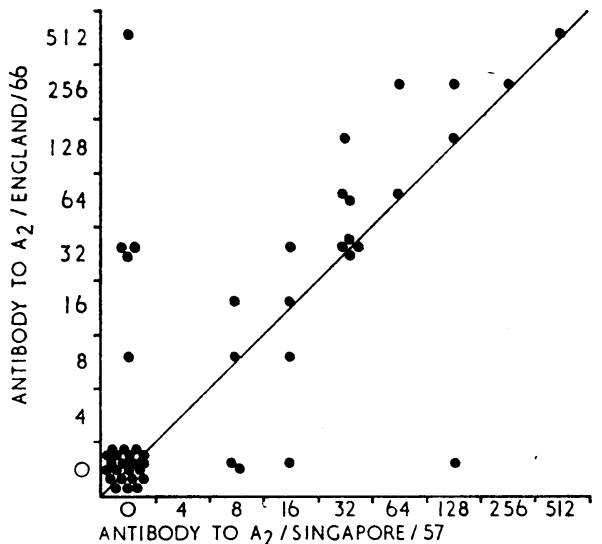

Fig. 4.-Antibody titres to $A_{2} / 57$ and $A_{2} / 66$ in individual children under 5 years.

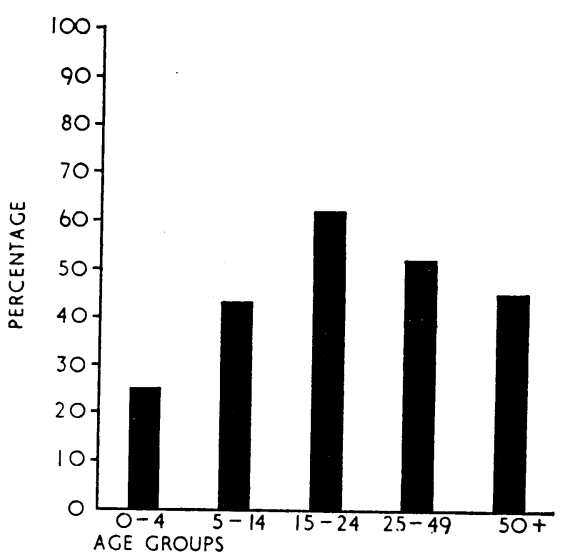

Fig. 5.-Percentage of individuals with antibody to $B /$ England/ 66 by age groups-all areas. January to May 1966. 
the prevalence of immunity in the population by a survey of the influenza antibody titres over a wide range of age groups. In the present investigation these titres have been estimated in samples of serum from a large number of individuals of various ages in five areas of England.

More than 1,700 sera were tested, but the numbers of samples from most of the age groups were rather limited. A more selective investigation in additional areas would be necessary to confirm that the results obtained were truly representative of the titres in the general population. However, the results give a general indication of the proportion of persons with antibody in many areas in England.

The strain-specific complement-fixation test was found in practice to be very suitable for a survey of this kind, since it is simple and quick with a clearly recognizable end-point.

A previous investigation (to be published) showed that infection with influenza $A_{2}$ virus was followed by the production of antibody which could be detected equally well by the haemagglutination inhibition, serum neutralization, and strainspecific complement-fixation test and which persisted for at least nine years. In a few instances the complement-fixing and haemagglutination-inhibiting antibody had declined to a low titre by this time and occasionally even became undetectable, whereas neutralizing antibody could be demonstrated convincingly on all occasions. On this basis the results obtained by the present complement-fixation tests must be regarded as providing a modest estimate of the proportion of the population that possess antibody.

If, as seems probable, the presence of circulating antibody is accepted as indicating some degree of resistance to influenza, the findings clearly indicate that a substantial proportion of each age group in England is protected against the current strains of influenza virus. It follows, therefore, that until the antigenicity of the influenza strains is altered a widespread epidemic of influenza is unlikely in England.

The investigation demonstrated the heterogeneity of antibody to the influenza $A_{2}$ strains because antibody to one strain may appear after infection with another. This is evident from the findings in children under 5 years old. In this group most of those with antibody to the $A_{2} /$ England/129/66 strain also had antibody to the $A_{2} /$ Singapore $/ 1 / 57$ strain, though the children could not have been infected with the $A_{2} /$ Singapore/ $1 / 57$ strain, because it had disappeared from England before many of them were born; moreover, most of them were too old for maternal antibody to the $A_{2} /$ Singapore $/ 1 / 57$ strain to have persisted.

\section{Summary}

To obtain information on the susceptibility of communities to influenza viruses serum samples from 1,783 persons of all ages living in five different areas of England were examined. Strain-specific complement-fixation tests for antibody to influenza viruses were used.

The results indicated that antibody to both early and late antigenic variants of influenza $A_{2}$ virus and to influenza $B$ virus is widespread in all age groups. An epidemic due to the current strains is unlikely.

The strain-specific complement-fixation test was found to be highly suitable for this type of investigation.

We are grateful to Drs. B. Moore, C. E. D. Taylor, J. O'H. Tobin, and J. E. M. Whitehead, from the public health laboratories of Exeter, London, Manchester, and Coventry respectively, for sending us serum samples, and to Dr. T. Skeoch and Mr. H. Bell, of the Central Clinical Laboratory, Middlesbrough, for their help. We would like to thank two visiting workers from New Zealand, Dr. Jack Burton and Miss Marjorie Bennett, for their part in this investigation.

\section{REFERENCES}

Henle, W., Lief, F. S., and Fabiyi, A. (1958). Lancet, 1, 818.

Lief, F. S., and Henle, W. (1956). Virology, 2, 772.

Pereira, H., G., Pereira, M. S., and Law, V. G.' (1964). Bull. Wld Hlth Org., 31, 129.

\title{
Antibodies in Children's Sera for Serologically Different Recently Isolated Strains of Influenza Viruses $A_{2}$ and $B$
}

\author{
G. C. SCHILD,* B.SC., PH.D. ; C. H. STUART-HARRIS, † C.B.E., M.D., F.R.C.P.
}

Brit. med. F., 1967, 4, 82-84

The natural antigenic variation of the influenza viruses and its probable significance in relation to the sequence of epidemics and pandemics of human influenza is well known. In the case of the influenza $A, A_{1}$, and $A_{2}$ viruses the variation from one major antigenic form to another has occurred every ten or more years, but in between these happenings there have been minor variations with a progressive deviation from the prototype. In the case of the influenza $B$ viruses it has not proved possible to group strains into families arranged in a chronological sequence of occurrence as with influenza $A$ viruses, and the variation appears to have been relatively haphazard. The serological impact of the various races of both influenza $A$ and $B$ on the population has been studied by many workers. Davenport et al. (1953) were the first to show that different age-cohorts of the population exhibit different serological spectra against the major influenza A virus families. They attributed their findings to a dominating influence on the

* Department of Bacteriology, University of Sheffield.

t Department of Medicine, University of Sheffield. immunological mechanism of childhood infection by the particular virus serotype then prevalent. Reinforcement of this antibody production by subsequent exposure to other serotypes occurs during adult life. Their doctrine of " original antigenic sin" or serological recapitulation of childhood antibodies has received support from numerous observations, including those derived from prospective studies on the same persons (Schild and Stuart-Harris, 1965).

The serological effects on man of minor antigenic variations occurring in interpandemic periods have, however, received little attention. Zhdanov (1967) has attempted to predict the occurrence of epidemics by examining sera with different serotypes represented by viruses isolated recently and from less recent epidemics. In such work children's sera are likely to yield more definitive information than those of adults because of the relatively specific character of the antibody response in childhood. The success of the Russian method in predicting the 1965 epidemic of $A_{2}$ and the 1967 outbreak of $B$ influenza (Zhdanov et al., 1966; Zhdanov, 1967) indicates that it is 